\title{
Comparison of methane production between C3 and C4 grasses and legumes
}

\author{
H. Archimède ${ }^{a}, *$, M. Eugène ${ }^{b}$, C. Marie Magdeleine ${ }^{a}$, M. Boval ${ }^{a}$, C. Martin $^{b}$, \\ D.P. Morgavi ${ }^{b}$, P. Lecomte ${ }^{c}$, M. Doreau ${ }^{b}$
}

a UR143, INRA (Institut National de la Recherche Agronomique), Unité de Recherches Zootechniques, F-97170 Prise d'Eau Petit-Bourg, Guadeloupe, France

b UR1213, INRA (Institut National de la Recherche Agronomique) Unité de Recherches sur les Herbivores, F-63122 Saint-Genès-Champanelle, France

' UMR Systemes d'Elevage en Régions Chaudes, CIRAD (Centre de coopération internationale en recherche agronomique pour le développement) F-34060

Montpellier, France

\section{A R T I C L E I N F O}

\section{Keywords:}

Methane production

Ruminants

Tropical forages

Temperate forages

Meta-analysis

\begin{abstract}
A B S T R A C T
A meta-analysis was conducted to compare effects of C4 and C3 grasses as well as warm and cold climate legumes on $\mathrm{CH}_{4}$ production of ruminants. For this purpose, a database was built using 22 in vivo studies containing 112 observations with 58 C3 grasses, 28 C4 grasses, 26 cold legumes and 12 warm legumes. Neutral detergent fibre (NDF), crude protein (CP) and total tract organic matter (OM) digestibility ranged from 415 to $753 \mathrm{~g} / \mathrm{kg} \mathrm{DM}$ versus 361 to $754 \mathrm{~g} / \mathrm{kg} \mathrm{DM}$, from 24 to $254 \mathrm{~g} / \mathrm{kg}$ DM versus 44 to $314 \mathrm{~g} / \mathrm{kg}$ DM and from 0.51 to 0.71 versus 0.56 to 0.83 for $\mathrm{C} 4$ and $\mathrm{C} 3$ grasses, respectively. The NDF, CP and total tract OM digestibility ranged from 441 to $690 \mathrm{~g} / \mathrm{kg} \mathrm{DM}$ versus 252 to $684 \mathrm{~g} / \mathrm{kg} \mathrm{DM}$, from 93 to $236 \mathrm{~g} / \mathrm{kg}$ DM versus 141 to $269 \mathrm{~g} / \mathrm{kg}$ DM and from 0.42 to 0.57 versus 0.38 to 0.79 for warm and cold legumes, respectively. Relationships between $\mathrm{CH}_{4}$ production and forage characteristics were analysed by analysis of covariance. For grasses, the main factors tested as fixed effects were NDF and CP content of the diet, total tract OM digestibility, intake, animal species, forage family and random trial effect. For legumes, tannin level was included in the model. Results indicate that ruminants fed $\mathrm{C} 4$ grass produced $17 \%$ more $\mathrm{CH}_{4}$ as $\mathrm{L} / \mathrm{kg} \mathrm{OM}$ intake $(\mathrm{P}<0.05)$ compared to those fed $\mathrm{C} 3$ grass. Animals fed warm legumes produced $20 \%$ less $\mathrm{CH}_{4}(\mathrm{P}<0.05)$ than those fed $\mathrm{C} 4$ grasses. In contrast, no difference in $\mathrm{CH}_{4}$ production between $\mathrm{C} 3$ grasses and cold legumes. Use of some legumes in warm climates could be a strategy to reduce $\mathrm{CH}_{4}$ emissions by ruminants.

This paper is part of the special issue entitled: Greenhouse Gases in Animal Agriculture Finding a Balance between Food and Emissions, Guest Edited by T.A. McAllister, Section Guest Editors: K.A. Beauchemin, X. Hao, S. McGinn and Editor for Animal Feed Science and Technology, P.H. Robinson.
\end{abstract}

(C) 2011 Elsevier B.V. All rights reserved.

Abbreviations: DM, dry matter; DOM, digestible OM; LW, live weight; NDF, neutral detergent fibre; NDFf, forage neutral detergent fibre; OM, organic matter; OMd, OM apparent digestibility.

* Corresponding author. Tel.: +33 590 255941; fax: +33 590255936.

E-mail address: Harry.Archimede@antilles.inra.fr (H. Archimède). 


\section{Introduction}

Diet composition and intake are main factors affecting $\mathrm{CH}_{4}$ production by ruminants. Ruminants fed forages rich in structural carbohydrate produce more $\mathrm{CH}_{4}$ than those fed mixed diets containing higher levels of non-structural carbohydrates (Sauvant and Giger-Reverdin, 2009). Forages are often the main ingredient in ruminant diets in the tropics. In these regions, feed resources (i.e., grasses, legumes, tree foliage) differ from those of temperate regions due to their chemical and structural composition and digestibility (Leng, 1990; Assoumaya et al., 2007). Tropical grasses generally use C4 metabolic pathways for photorespiration whereas most temperate grasses use C3 carbon fixation. Often, the C4 metabolic pathway leads to a higher rate and degree of deposition of lignin in plant tissues, a factor which can alter voluntary intake and digestion (Wilson, 1994), although there are exceptions. Some tropical forages, such as legumes, shrubs and tree foliages may contain secondary metabolites such as condensed tannins and saponins that alter rumen methanogenesis (Jouany and Morgavi, 2007).

It has been reported that ruminants fed tropical forages produce more $\mathrm{CH}_{4}$ than ruminants fed temperate forages (McCrabb and Hunter, 1999). Also, the presence of condensed tannins in legume, tree and shrub foliage has been found to lower $\mathrm{CH}_{4}$ emissions (Waghorn, 2008) mainly due to inhibition of methanogens in the rumen (Martin et al., 2010). However, studies based on direct in vivo comparison of C4 versus C3 grass, or of legumes grown in warm ('warm' legume) versus cold environments ('cold' legume) have been rare due to geographical constraints.

Our objective was to compare $\mathrm{CH}_{4}$ emissions of ruminants fed $\mathrm{C} 4$ versus $\mathrm{C} 3$ grass, and warm versus cold legumes using a meta-analysis approach with consideration for explanatory factors such as dietary fibre content, total tract digestibility and intake.

\section{Materials and methods}

\subsection{Publications selection and codification for the database}

The database used contained 112 treatments extracted from 22 scientific publications. To be included, a publication had to contain data on forage composition, feed intake, digestibility and $\mathrm{CH}_{4}$ emission measurements. Only all forage diets were included and cereal forages, such as corn and sorghum, were not included. Forages were classified into grasses and legumes. A grass was assigned as C4 when it had a C4 metabolic pathway, which is characteristic of tropical grasses, and it was harvested in the tropics. A grass was assigned as C3 when it had a C3 metabolic pathway, which is characteristic of temperate grasses, and it was harvested in temperate environments. As all legumes have C3 metabolic pathways, they were classified into 'warm' and 'cold' types. A warm type was defined as being grown mainly in a tropical environment, and occasionally in a temperate environment during the warm season. A cold type was defined as being grown in a temperate environment. C4 grasses and warm legumes were defined as tropical forages, and C3 grasses and cold legumes were defined as temperate forages. This classification resulted in a distribution of studies among forage types of C3 grass $(n=58)$, cold legume ( $n=14)$, C4 grass $(n=28)$ and warm legume $(n=12)$. As $\mathrm{CH}_{4}$ production has been shown to be affected by tannins (Waghorn, 2008), legumes were coded according to their tannin concentration. Three levels, being high, medium and low were defined on the basis of literature data. High concentrations corresponded to more than $300 \mathrm{~g}$ tannin $/ \mathrm{kg}$ DM, medium concentration included legumes with 100-300 g tannin/ $\mathrm{kg}$ DM and low included those legumes containing less than $100 \mathrm{~g}$ tannin/kg DM. Animal species were coded as large (i.e., cows, heifers, calves; $n=62$ ) and small (i.e., sheep, goats; $n=50$ ) ruminants. The methods used to measure $\mathrm{CH}_{4}$ were coded as: calorimetric chamber, $\mathrm{SF}_{6}$ gas tracer technique and gas bag technique.

\subsection{Calculations}

Some estimates were made of organic matter (OM) level of the diet and OM digestibility when data were lacking in the publications. The OM content of diet and OM digestibility were estimated as DM multiplied by 0.9 and DM digestibility multiplied by 1.05 , respectively, according to tables of feed values in temperate and tropical countries. The $\mathrm{CH}_{4}$ production was expressed in litres or per unit of DM intake $(\mathrm{kg}),(\mathrm{L} / \mathrm{kg}$ DM intake), OM intake $(\mathrm{kg})(\mathrm{L} / \mathrm{kg}$ OM intake), or digested OM (L/g DOM).

\subsection{Statistical analyses}

The meta-analysis followed recommendations of Sauvant et al. (2008) using Minitab (2007). Variation in predictability of $\mathrm{CH}_{4}$ production attributable to a number of variables including OM intake, neutral detergent fibre (NDF) intake, digestible OM intake, forage NDF (NDFf) and OM digestibility (OMd) was examined. Level of intake was considered using the OM intake/liveweight (LW) ${ }^{0.9}$ (Poppi et al., 1990) as covariates. Predictions of $\mathrm{CH}_{4}$ production were similar to those obtained with LW as a covariate. Several qualitative factors were accounted for, such as type of forage (C3 grass, cold legume, C4 grass, warm legume), animal species (large and small ruminants), $\mathrm{CH}_{4}$ measurement method (calorimetric chamber, $\mathrm{SF}_{6}$ gas tracer technique, gas bag technique) and tannin level (low, medium and high). Moreover a random effect of study ( $n=22)$ was also included in the model. 
Table 1

Statistical description of the chemical composition for each type of forage or animals in the database.

\begin{tabular}{|c|c|c|c|c|c|}
\hline & \multirow[t]{2}{*}{ Parameter } & \multicolumn{2}{|l|}{ Grasses } & \multicolumn{2}{|l|}{ Legumes } \\
\hline & & C3 type & C4 type & Cold & Warm \\
\hline & $n$ & 58 & 28 & 14 & 12 \\
\hline $\begin{array}{l}\text { NDF } \\
(\mathrm{g} / \mathrm{kg} \mathrm{DM})\end{array}$ & $\begin{array}{l}\text { Mean } \\
\text { SD } \\
\text { Minimum } \\
\text { Maximum }\end{array}$ & $\begin{array}{c}557.3 \\
84.81 \\
361.0 \\
754.0\end{array}$ & $\begin{array}{c}646.4 \\
97.89 \\
415.0 \\
753.0\end{array}$ & $\begin{array}{l}447.2 \\
114.67 \\
252.0 \\
684.0\end{array}$ & $\begin{array}{c}568.2 \\
98.94 \\
441.0 \\
690.0\end{array}$ \\
\hline $\begin{array}{l}\mathrm{CP} \\
(\mathrm{g} / \mathrm{kg} \mathrm{DM})\end{array}$ & $\begin{array}{l}\text { Mean } \\
\text { SD } \\
\text { Minimum } \\
\text { Maximum }\end{array}$ & $\begin{array}{c}169.5 \\
55.94 \\
44.0 \\
314.0\end{array}$ & $\begin{array}{c}110.3 \\
62.80 \\
24.0 \\
254.0\end{array}$ & $\begin{array}{c}198.6 \\
38.40 \\
141.0 \\
269.0\end{array}$ & $\begin{array}{c}156.6 \\
56.91 \\
93.0 \\
236.0\end{array}$ \\
\hline $\begin{array}{l}\text { OM intake } \\
(\mathrm{g} / \mathrm{kg} \mathrm{LW})\end{array}$ & $\begin{array}{l}\text { Mean } \\
\text { SD } \\
\text { Minimum } \\
\text { Maximum }\end{array}$ & $\begin{array}{c}19.8 \\
5.48 \\
10.6 \\
33.9\end{array}$ & $\begin{array}{c}17.7 \\
6.98 \\
7.4 \\
31\end{array}$ & $\begin{array}{c}17.8 \\
6.00 \\
9.3 \\
28.8\end{array}$ & $\begin{array}{c}18.6 \\
4.57 \\
7.3 \\
25.2\end{array}$ \\
\hline $\begin{array}{l}\text { OM } \\
\text { intake } \\
\left(\mathrm{g} / \mathrm{kg} \mathrm{LW}^{0.9}\right)\end{array}$ & $\begin{array}{l}\text { Mean } \\
\text { SD } \\
\text { Minimum } \\
\text { Maximum }\end{array}$ & $\begin{array}{c}34.4 \\
8.27 \\
15.7 \\
48.9\end{array}$ & $\begin{array}{l}27.4 \\
11.81 \\
10.7 \\
56.9\end{array}$ & $\begin{array}{c}31.4 \\
9.30 \\
13.8 \\
51.1\end{array}$ & $\begin{array}{c}25.6 \\
6.44 \\
10.7 \\
36.3\end{array}$ \\
\hline $\begin{array}{l}\text { OM apparent total } \\
\text { tract digestibility }\end{array}$ & $\begin{array}{l}\text { Mean } \\
\text { SD } \\
\text { Minimum } \\
\text { Maximum }\end{array}$ & $\begin{array}{l}0.70 \\
0.075 \\
0.56 \\
0.83\end{array}$ & $\begin{array}{l}0.62 \\
0.057 \\
0.51 \\
0.71\end{array}$ & $\begin{array}{l}0.63 \\
0.010 \\
0.38 \\
0.79\end{array}$ & $\begin{array}{l}0.48 \\
0.053 \\
0.42 \\
0.57\end{array}$ \\
\hline
\end{tabular}

Those variables that accounted for the majority of the predictability of $\mathrm{CH}_{4}$ production, and were adequately represented among studies, were selected for the final model and included the factors: random study effect, forage, level of intake (OM intake/LW $\left.{ }^{0.9}\right)$, OMd and NDFf. The statistical analysis model of the database was:

$$
y_{i j k}=\mu+a_{i}+b_{j}+\alpha \mathrm{OM}_{\text {intake }}+\beta \mathrm{OM}_{\text {digestibility }}+\delta \mathrm{NDF}_{\text {content }}+\varepsilon_{i j k}
$$

where $y_{i j k}$ is the $\mathrm{CH}_{4}$ production, $a_{i}$ is the $i$ th random trial effect $(i=1, \ldots, 22), b_{j}$ is the $j$ th forage type $(j=1, \ldots, 4), \alpha$ is the coefficient associated with the covariable OM intake, $\beta$ is the coefficient associated with the covariable OM digestibility, $\delta$ is the coefficient associated with the covariable NDF content and $\varepsilon_{i j k}$ is the residual error.

When a treatment was an outlier (i.e., beyond 3 standard deviations from the adjusted mean) for a character or a specific relationship, it was removed from the statistical analysis.

An analysis of variance was completed on legumes to estimate tannin level effect on $\mathrm{CH}_{4}$ production. Studies and tannins levels were considered as fixed effects. MOI/LW ${ }^{0.9}$, OMd and NDFf were used as covariates in the model:

$$
y_{i j k}=\mu+a_{i}+b_{j}+\alpha \mathrm{OM}_{\text {intake }}+\beta \mathrm{OM}_{\text {digestibility }}+\delta \mathrm{NDF}_{\text {content }}+\varepsilon_{i j k}
$$

where $y_{i j k}$ is the $\mathrm{CH}_{4}$ production of legumes, $a_{i}$ is the $i$ th random trial effect $(i=1, \ldots, 7), b_{j}$ is the $j$ th tannin level $(j=1, \ldots, 3), \alpha$ is the coefficient associated with the covariable OM intake, $\beta$ is the coefficient associated with the covariable OM digestibility, $\delta$ is the coefficient associated with the covariable NDF content and $\varepsilon_{i j k}$ is the residual error.

\section{Results}

\subsection{Database characteristics}

Studies included in the model are in Table 1, with at least 3 studies contributing to the mean values. Data included 50 studies in small ruminants ( 8 goats and 42 sheep) and 62 studies in large animals (34 cows, 21 heifers, 7 calves). Tropical forages are underrepresented relative to temperate forages, and grasses have been studied more than legumes. Whatever the origin of forage, the variation in chemical composition and digestibility is broad and representative of forage diversity.

\subsection{Methane production and diet}

Those measured components that had the closest relationship to aspects of methane production included:

$$
\begin{aligned}
\mathrm{CH}_{4} \quad \mathrm{~L} / \mathrm{kg} \quad \text { DMintake }= & -4.2( \pm 11.3)+39.2( \pm 9.2) \times \mathrm{OMd}+21.1( \pm 11.4) \times \mathrm{NDFf}-0.15( \pm 0.06) \\
& \times \mathrm{OM} \quad \text { intake } / \mathrm{LW}^{0.9} \quad\left(n=115, \quad R^{2}=0.77, \quad \text { rsd }=4.1, \quad \mathrm{P}<0.0001\right)
\end{aligned}
$$


Table 2

Effect of forage type on $\mathrm{CH}_{4}$ production, expressed as $\mathrm{L} / \mathrm{kg}$ dry matter (DM) intake, $\mathrm{L} / \mathrm{kg}$ organic matter (OM) intake, $\mathrm{L} / \mathrm{kg}$ digested OM (DOM) or L/100 kg live weight $(\mathrm{LW})$.

\begin{tabular}{|c|c|c|c|}
\hline & $\mathrm{CH}_{4}$ (L/kg DM intake) & $\mathrm{CH}_{4}(\mathrm{~L} / \mathrm{kg}$ OM intake) & $\mathrm{CH}_{4}(\mathrm{~L} / \mathrm{kg} \mathrm{DOM})$ \\
\hline \multicolumn{4}{|l|}{ Grasses } \\
\hline C3 type & $30.0 \mathrm{~b}$ & $33.1 \mathrm{~b}$ & $52.1 \mathrm{~b}$ \\
\hline C4 type & $33.7 c$ & $38.8 \mathrm{c}$ & $57.7 \mathrm{~b}$ \\
\hline \multicolumn{4}{|l|}{ Legumes } \\
\hline Cold & $30.1 b$ & $33.7 \mathrm{bc}$ & $52.4 b$ \\
\hline Warm & $25.9 a$ & $27.2 \mathrm{a}$ & $40.7 \mathrm{a}$ \\
\hline SEM & 1.77 & 1.79 & 2.89 \\
\hline$R^{2}$ & 0.77 & 0.84 & 0.76 \\
\hline $\mathrm{P}$ & 0.001 & 0.001 & 0.001 \\
\hline
\end{tabular}

Mean values within column with no common letter $(\mathrm{a}-\mathrm{c})$ differ $(\mathrm{P}<0.05)$. Effects used in the model were: experiment, animal species, diet, forage NDF content, OM apparent total tract digestibility and OM intake/LW $\mathrm{LW}^{0.9}$.

$$
\begin{gathered}
\mathrm{CH}_{4} \quad \mathrm{~L} / \mathrm{kg} \quad \text { OMintake }=0.9( \pm 11.4)+39.8( \pm 3.1) \times \mathrm{OMd}+18.9( \pm 11.49) \times \mathrm{NDFf}-0.2( \pm 0.06) \times \mathrm{OM}_{\text {intake } / \mathrm{LW}^{0.9}} \\
\left(n=115, \quad R^{2}=0.84, \quad \text { rsd }=4.1, \quad \mathrm{P}<0.0001\right) \\
\mathrm{CH}_{4} \quad \mathrm{~L} / \mathrm{kg} \quad \text { OMD }=34.1( \pm 9.6)+40.4( \pm 15.2) \times \mathrm{NDFf}-0.3( \pm 0.09) \times \mathrm{OM} \quad \text { intake } / \mathrm{LW}^{0.9} \\
\left(n=115, \quad R^{2}=0.76, \quad \text { rsd }=6.6, \quad \mathrm{P}<0.0001\right)
\end{gathered}
$$

However, the accuracy of the models differed depending on how $\mathrm{CH}_{4}$ production was expressed, with accuracy higher when $\mathrm{CH}_{4}$ production was expressed as $\mathrm{L} / \mathrm{kg}$ OM intake. Whatever the mode of expression of $\mathrm{CH}_{4}$, there were no interactions between class of forage and NDFf or between class of forage and OMd. As expected, $\mathrm{CH}_{4}$ production increased with increasing NDF content and OMd of the diet, and decreased with declining intake.

Methane production was higher for animals fed C4 grasses (Table 2) compared to those fed C3 grasses regardless of how $\mathrm{CH}_{4}$ production was expressed. Methane production was lower for animals fed warm legumes compared to those fed cold legumes.

A specific statistical analysis of legumes $\left(n=25, R^{2}=0.92\right.$, rsd $\left.=2.6, \mathrm{P}=0.01\right)$, indicated that $\mathrm{CH}_{4}$ production (L/OM intake) was lower for animals fed high tannin legumes $(21.8 \mathrm{~L} / \mathrm{kg}$ MOI versus $27.8 \mathrm{~L} / \mathrm{kg}$ MOI) compared to those fed low tannin legumes. The same model $\left(n=25, R^{2}=0.80, \mathrm{rsd}=5.6, \mathrm{P}=0.01\right)$ resulted in estimates of $37.2 \mathrm{~L} / \mathrm{kg} \mathrm{DOM}$ intake versus $52.2 \pm 2.7 \mathrm{~L} / \mathrm{kg}$ DOM intake for high tannin legumes versus low tannin legumes.

\section{Discussion}

The main objective was to compare $\mathrm{CH}_{4}$ production in ruminants fed tropical or temperate forages. Some publications support the hypothesis that tropical C4 grasses are more methanogenic than temperate C3 grasses (Kurihara et al., 1999;

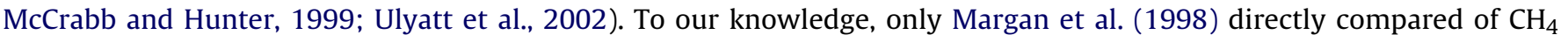
production between two tropical forages and a temperate forage in the same study. Most comparisons are based on data obtained under different situations. Other conclusions come from inference of the positive correlation between forage fibre level and $\mathrm{CH}_{4}$ production (Blaxter and Wainman, 1964; Moe and Tyrrell, 1979). As tropical forages are usually higher in fibre than temperate forages, many models assign higher estimates of $\mathrm{CH}_{4}$ production to them. However, this criterion does not consider the wide variability in fibre contents that exist within tropical and temperate forage groups with broad overlaps between these forage classes.

Our meta-analysis compared tropical and temperate forages at the same level of fibre, digestibility and level of intake. It demonstrated that $\mathrm{CH}_{4}$ production for $\mathrm{C} 4$ grasses was $10-17 \%$ higher, depending on the unit, compared to $\mathrm{C} 3$ grasses. In contrast, $\mathrm{CH}_{4}$ production from legumes grown in warm climates was $7-22 \%$ lower than for legumes grown in cold climates. These values can be compared with those of Margan et al. (1998) who found that sheep fed C4 grasses produced 23\% more $\mathrm{CH}_{4}(\mathrm{MJ} / \mathrm{MJ}$ intake) than sheep consuming a C3 grass, but only two C4 grasses were studied. Differences between C4 and C3 grasses occurred when $\mathrm{CH}_{4}$ production was expressed as L/OM intake and L/DOM intake. These differences were not due to a lower digestibility for $\mathrm{C} 4$ grasses because the forages were adjusted for digestibility by inclusion of this variable as a covariate in the model. While intake and NDF content were included as covariables in the model, differences in $\mathrm{CH}_{4}$ production between C4 and C3 grasses persisted. However, the nature of the fibre differs between tropical and temperate forages (Wilson, 1994) with C4 grass fibres tending to be more lignified and more resistant to physical and microbial digestion than those of $\mathrm{C} 3$ grasses. At the same level of digestibility, tropical grasses also have a longer retention time in the rumen (Assoumaya, 2007). This difference in rumen retention between $\mathrm{C} 4$ and $\mathrm{C} 3$ grasses may account for a portion of the difference in $\mathrm{CH}_{4}$ production. Others have shown that increasing retention time of forages in the rumen can lead to increased $\mathrm{CH}_{4}$ production (Pinares-Patino et al., 2003). 
The VFA profile could help to explain differences in $\mathrm{CH}_{4}$ production between $\mathrm{C} 3$ and $\mathrm{C} 4$ grasses. Unfortunately, to our knowledge, neither in vivo nor in vitro experiments have been completed to compare VFA profiles between C3 and C4 grasses. Data from the comparison of old and young re-growth of C4 grass, which approximates digestion of C3 grass (Assoumaya, 2007), could be of interest. Assoumaya (2007) compared digestion of the C4 plant Panicum maximum between 14 and 56 days of re-growth and found a decrease in propionate relative to total VFA, while acetate increased with advancing maturity. Rumen fermentation profiles could therefore partially explain differences between temperate and tropical grasses. However, variation of $\mathrm{CH}_{4}$ production among the 5 types of forage is lower than that in mixed diets where the proportion of forage and concentrate varies (Johnson and Johnson, 1995). This likely reflects the small change in the ratio of propionate/acetate ratios in forages fed to ruminants in contrast to mixed diets (Johnson and Johnson, 1995).

Compared to grasses, legumes have at least two characteristics which could influence OM digestion in the rumen and, consequently, $\mathrm{CH}_{4}$ production. The highly lignified cell walls and the presence of secondary metabolites such as tannins decrease cell wall digestion in legumes. Notwithstanding, there is high variability among legumes, in particular regarding the presence of secondary metabolites such as tannins which are more common in tropical versus temperate legumes (Waghorn, 2008). In our database, the legumes highest in tannin were those of tropical origin, a factor that could account for the lower $\mathrm{CH}_{4}$ production in warm versus cold legumes. Studies conducted in vitro (Bekele et al., 2009; Soliva et al., 2008; Tiemann et al., 2008) have shown that a large portion of the variability of $\mathrm{CH}_{4}$ production in legumes can be accounted for by the presence or absence of secondary metabolites. In temperate conditions, fresh lucerne has been shown to produce less $\mathrm{CH}_{4}$ than grasses (McCaughey et al., 1999), whereas clover did not (Van Dorland et al., 2007). Similarly, studies with temperate legumes found high variability in $\mathrm{CH}_{4}$ production in ruminants depending on the presence or absence of secondary metabolites (Waghorn et al., 2002; Waghorn, 2008; Beauchemin et al., 2009; Dewhurst et al., 2009).

\section{Conclusions}

When fed to ruminants, it is clear that $\mathrm{C} 4$ grasses produce more $\mathrm{CH}_{4}$ than $\mathrm{C} 3$ grasses, that legumes from warm climates produce less $\mathrm{CH}_{4}$ than legumes from cold climates, and that legumes produce less $\mathrm{CH}_{4}$ than grasses.

The relative scarcity of data on $\mathrm{CH}_{4}$ production from ruminants fed tropical forages (i.e., $\mathrm{C} 4$ grasses and warm legumes) suggests a need for additional studies. Results of this meta-analysis should be confirmed by coordinated experiments in temperate and tropical environments with the same animal genotype (i.e., tropical versus temperate) fed both tropical and temperate forages.

\section{Conflict of interest statement}

None.

\section{Acknowledgements}

This study was completed with the financial support of the "ANR - The French National Research Agency", project "ANR-09-STRA-01 EPAD”. References included in the database can be obtained by request from the corresponding author.

\section{References}

Assoumaya, C., 2007. Etude des facteurs limitant l'ingestion chez les petits ruminants valorisant des fourrages tropicaux. PhD Thesis, Agro Paris Tech., Paris, France, $298 \mathrm{pp}$.

Assoumaya, C., Sauvant, D., Archimède, H., 2007. Etude comparative de l'ingestion et de la digestion des fourrages tropicaux et tempérés. INRA Prod. Anim. 20, 383-392.

Bekele, A.Z., Clement, C., Kreuzer, M., Soliva, C.R., 2009. Efficiency of Sesbania sesban and Acacia angustissima in limiting methanogenesis and increasing ruminally available nitrogen in a tropical grass-based diet depends on accession. Anim. Prod. Sci. 49, 145-153.

Beauchemin, K.A., McAllister, T.A., McGinn, S.M., 2009. Dietary mitigation of enteric methane from cattle. CAB Reviews: Perspectives in Agriculture, Veterinary Science, Nutrition and Natural Resources 4 (035).

Blaxter, K.L., Wainman, F.W., 1964. The utilization of the energy of different rations by sheep and cattle for fattening. J. Agric. Sci. 63, $113-128$.

Dewhurst, R.J., Delaby, L., Moloney, A., Boland, T., Lewis, E., 2009. Nutritive value of forage legumes used for grazing and silage. Irish J. Agric. Food Res. 48, $167-187$.

Johnson, K.A., Johnson, D.E., 1995. Methane emissions from cattle. J. Anim. Sci. 73, 2483-2492.

Jouany, J.P., Morgavi, D.P., 2007. Use of 'natural' products as alternatives to antibiotic feed additives in ruminant production. Animal 1, $1443-1466$.

Kurihara, M., Magner, T., Hunter, R.A., McCrabb, G.J., 1999. Methane production and energy partition of cattle in the tropics. Brit. J. Nutr. 81, 227-234.

Leng, R.A., 1990. Factors affecting the utilization of poor-quality forages by ruminants particularly under tropical conditions. Nutr. Res. Rev. $3,277-303$.

Martin, C., Morgavi, D.P., Doreau, M., 2010. Methane mitigation in ruminants: from microbe to the farm scale. Animal 4, $351-365$.

Margan, D.E., Graham, N.M., Minson, D.J., Searle, T.W., 1998. Energy and protein values of four forages including comparison between tropical and temperate species. Aust. J. Exp. Agr. 128, 729-736.

McCrabb, G.J., Hunter, R.A., 1999. Prediction of methane emissions from beef cattle in tropical production systems. Aust. J. Agric. Res. 50, $1335-1339$.

McCaughey, W.P., Wittenberg, K., Corrigan, D., 1999. Impact of pasture type on methane production by lactating beef cows. Can. J. Anim. Sci. 79, $221-226$.

Moe, P.W., Tyrrell, H.F., 1979. Methane production in dairy cows. J. Dairy Sci. 62, 1583-1586.

Pinares-Patino, C.S., Ulyatt, M.J., Lassey, K.R., Barry, T.N., Holmes, C.W., 2003. Rumen function and digestion parameters associated with differences between sheep in methane emissions when fed chaffed lucerne hay. J. Agric. Sci. 140, 205-214.

Poppi, D.P., Minson, D.J., Ternouth, J.H., 1990. Studies of cattle and sheep eating leaf and stem fractions of grasses. 1. The voluntary intake, digestibility and retention time in the reticulorumen. Aust. J. Agric. Res. 32, 99-108.

Sauvant, D., Schmidely, P., Daudin, J.J., St-Pierre, N.R., 2008. Meta-analysis of experimental data in animal nutrition. Animal 2, $1203-1214$. 
Sauvant, D., Giger-Reverdin, S., 2009. Modélisation des interactions digestives et de la production de méthane. Inra Prod. Anim. 22 , 375-384.

Soliva, C.R., Zeleke, A.B., Clement, C., Hess, H.D., Fievez, V., Kreuzer, M., 2008. In vitro screening of various tropical foliages, seeds, fruits and medicinal plants for low methane and high ammonia generating potentials in the rumen. Anim. Feed Sci. Technol. 147, 53-71.

Tiemann, T.T., Lascano, C.E., Kreuzer, M., Hess, H.D., 2008. The ruminal degradability of fibre explains part of the low nutritional value and reduced methanogenesis in highly tanniniferous tropical legumes. J. Sci. Food Agric. 88, 1794-1803.

Ulyatt, M.J., Lassey, K.R., Shelthon, I.D., Walker, F., 2002. Methane emission from dairy cows and wether sheep fed subtropical grass-dominant pastures in midsummer in New Zealand. N. Z. J. Agric. Res. 45, 227-234.

Waghorn, G., 2008. Beneficial and detrimental effects of dietary condensed tannins for sustainable sheep and goat production: progress and challenges. Anim. Feed Sci. Technol. 147, 116-139.

Waghorn, G.C., Tavendale, M.H., Woodfield, D.R., 2002. Methanogenesis from forages fed to sheep. Proc. N. Z. Soc. Grassland Assoc. 64, $59-65$.

Van Dorland, H.A., Wettstein, H.R., Leuenberger, H., Kreuzer, M., 2007. Effect of supplementation of fresh and ensiled clovers to ryegrass on nitrogen loss and methane emissions in dairy cows. Livest. Sci. 111, 57-69.

Wilson, J.R., 1994. Cell wall characteristics in relation to forage digestion by ruminants. J. Agric. Sci. 122, $173-182$. 